\title{
Techniques of Bridging the Gulf: Dialectic and Reductionism in McDowell and Fichte
}

\author{
Jens Lemanski \\ (University of Hagen, Institute for Philosophy)
}

\section{Introduction}

Although "dialectic" is not a widely used term in contemporary analytical philosophy, it has become increasingly interesting for analytic philosophers after the so-called Hegelian turn. ${ }^{1}$ For instance, there are some remarks in Robert Brandom's and John McDowell's work concerning the dialectical process of Hegel. ${ }^{2}$ This is not surprising, since dialectic as a method of theoretical philosophy has a great influence on the methodological investigation of topics of practical philosophy, e.g. theories of role models, love or recognition. ${ }^{3}$ These remarks were also the starting point of new discussions about Hegelian dialectic ${ }^{4}$ and new studies

1 Cf. T. Rockmore, Analytic Philosophy and the Hegelian Turn, “The Review of Metaphysics" 2001, Vol. 55, No. 2, pp. 339-370, esp. pp. 359-354.

2 Cf. R. Brandom, Tales of the Mighty Dead: Historical Essays in the Metaphysics of Intentionality, Cambridge, MA 2002, p. 202 et seqq.; J. McDowell, Having the World in View: Essays on Kant, Hegel, and Sellars, Cambridge, MA 2009, p. 156 et seqq.

3 Cf. J. Lemanski, An Analogy between Hegel's Theory of Recognition and Ficino's Theory of Love, "British Journal for the History of Philosophy" 2019, Vol. 27, No. 1, pp. 95-113.

4 Cf. S. Houlgate, McDowell, Hegel, and the "Phenomenology of Spirit", "Owl of Minerva" 2009/10, Vol. 41, pp. 13-26; M. Gulli Inferenzialismo e dialettica speculativa: Robert Brandom e la lettura critica di Hegel, "Giornale di metafisica" 2007, Vol. 3, No. 2, pp. 731-756; J.E. Maybee, Hegel's Dialectics, in: The Stanford Encyclopedia of Philosophy (Winter 2019 Edition), ed. E.N. Zalta, URL: https://plato.stanford.edu/archives/win2019/entries/hegel-dialectics/. 
on comparisons between classical German(-language) philosophy and analytic philosophy. ${ }^{5}$ Most of these studies have shown that there is actually a certain dialectical approach in analytic philosophy after the Hegelian turn and especially in the philosophy of $\mathrm{McD}$ owell. In the case of McDowell's dialectic, these comparisons are not limited and should not be limited to Hegel, as e.g. Italo Testa or Tom Whyman have shown. ${ }^{6}$

Also, the present study is concerned with two paradigmatic texts on dialectic in classical German(-language) philosophy and analytic philosophy, i.e. Johann Gottlieb Fichte's Science of Knowing 1804 and John McDowell's Mind and World. I believe that both philosophers - despite many differences - follow a dialectical method in order to avoid one-sided reductionistic positions in philosophy. In other words, both are searching for techniques of "bridging" the gulf, separated by dualistic positions or concepts that reductionists use to take a position on one side and explain the opposite one from it. The main reason why Fichte's dialectical approach was selected here instead of, e.g., Schleiermacher's, Hegel's, or Adorno's, ${ }^{7}$ is a systematic one: I believe that Fichte's Sci-

The results of these comparisons can vary between two opinions: the first is that there is no dialectical approach in the "Pittsburgh neo-Hegelianism." This point of view can be represented by Nektarios Limnatis, who claims: "No functional equivalent of [Hegel's] dialectic is to be found in McDowell and Brandom [...]" (The Dimensions of Hegel's Dialectic, London 2010, p. 225). The second one refers to, e.g., a "dialectical character" of the relation between first and second nature in McDowell's Mind and World that can be compared with the thought of other dialectical philosophers, such as Theodor Adorno (cf. I. Testa, Criticism from Within Nature: The Dialectic Between First and Second Nature from McDowell to Adorno, "Philosophy \& Social Criticism" 2007, Vol. 33, p. 474). For example, in 2002 Brian Morrison has claimed that McDowell "works dialectically" (Mind, World and Language: McDowell and Kovesi, "Ratio: An International Journal of Analytic Philosophy" 2002, Vol. 15, No. 3, p. 295) and demonstrated his assertion by analyzing the argumentation of Mind and World. Previously, an entire study about dialectic in McDowell had been published by Fiona Ellis (On the Dismounting of Seesaws, "Philosophy" 2001, Vol. 76, No. 1, pp. 31-54).

6 Cf. I. Testa, Criticism from Within Nature, op. cit.; T. Whyman, The Irrational in the Rational, or: John McDowell's Dialectic of Enlightenment, "Inquiry: An Interdisciplinary Journal of Philosophy" 2018, pp. 1-23.

7 There are already some studies that emphasize differences and correlations between McDowell and Fichte (cf. G. di Giovanni, The Jacobi-Fichte-Reinhold Dialogue and Analytical Philosophy, "Fichte-Studien" 1998, Vol. 14, pp. 63-87; P. Dews, Nature and Subjectivity: Fichte's Role in the Pippin/McDowell Debate in the Light of His Neo-Kantian Reception, "Fichte-Studien" 2010, Vol. 35, pp. 227-243; V. Pluder, Die Vermittlung von Idealismus und Realismus in der Klassischen Deutschen Philosophie, Stuttgart-Bad Cannstatt 2013), but none of these has been focused directly on the two texts mentioned here. 
ence of Knowing 1804 can make a good contribution to McDowell's dialectical approach since Fichte focuses on the meta-debate between reductionism and anti-reductionism, which I think McDowell is losing sight of. ${ }^{8}$

Since I believe that McDowell dominates the current discussion and I understand Fichte's position as a systematic contribution to this debate, I will not proceed chronologically, but start with McDowell's approach in Section 2 and then present Fichte's position in Section 3. In both sections, I will try to give a systematic overview of their dialectic approaches in their very own formulations. However, for a better comparison of both positions, I will try to present the main results in Sections 2 and 3 in quasi-logical terms of the so-called bridge principles introduced by Ernest Nagel. ${ }^{9}$ (As I will explain at certain points, a mere logical representation of the given dialectic is problematic.) In Section 4, I interpret McDowell's dialectic as an alternative to the three reductionistic positions which he had discovered in current philosophy (4.1). As a consequence, I will argue that dialectic is a positive method of anti-reductionism that is different from normal anti-reductionistic positions, which are often equated with theoretical holism (or further theoretical individualism),$^{10}$ on the one hand, and which are normally just a negative refusal of reductionism, on the other. ${ }^{11}$ Furthermore, I will argue that Fichte reflects on the debate on reductionism and anti-reductionism itself and that in his opinion anti-reductionism has something quite similar to reductionism, so that the debate on reductionism and anti-reductionism can at least be interpreted as involved in dialectic argumentation (4.2). In my conclusion (Section 5), I will point out why dialectic can be an alternative to reductionism as well as to normal anti-reductionism.

8 McDowell's position often comes under suspicion of favouring the reductionistic position of conceptualism, even if McDowell tries to evade this reproach by making certain differentiations (cf. J. Browning McDowell and the Contents of Intuition, "Dialectica" 2019, Vol. 73, No. 1-2, pp. 83-104).

9 Cf. R. van Riel, Nagelian Reduction beyond the Nagel Model, "Philosophy of Science" 2011, Vol. 78, No. 3, pp. 353-375.

10 Cf. R.H. Jones, Reductionism: Analysis and the Fullness of Reality, Lewisburg 2000, pp. 212-217.

11 Cf. D. Pritchard, A Defence of Quasi-Reductionism in the Epistemology of Testimony, "Philosophica" 2006, Vol. 78, p. 20: “anti-reductionism' [...] implies a view which is simply the logical negation of reductionism rather than a positive proposal in its own right." 


\section{John McDowell's “Last Dualism”}

The first part of this section (2.1) describes McDowell's criticism of the methodology of recent philosophy and his counter-proposal, which is called the "naturalism of second nature." Part 2.2 is concerned with the dilemma of analytical epistemology in which McDowell is situated.

\subsection{The Bridge over the Gulf}

In $₫ 3$ of the fifth lecture in Mind and World, McDowell describes various kinds of dualisms. All "familiar dualisms of modern philosophy," he says, can be traced back to either a (1) "deeper dualism" or a (2) "last dualism." 12 In my view, both types of dualism are working terms that differ depending on their use. But McDowell differentiates these dualisms more precisely, gives them general titles, such as "phenomenalism," "platonism," "naturalism," etc., and assigns them to specific schools or authors of analytical philosophy. In any case, each dualism signifies an unwelcome gulf between concepts such as subject and object, thought and world, or norm and nature. This means that within the dualism, each side of the gulf is represented by a concept that is semantically distinct from the other. In McDowell's opinion, a central aim of modern philosophy is to remove the differences between both sides and concepts: "Modern philosophy has taken itself to be called on to bridge dualistic gulfs, between subject and object, thought and world."13

In considering the technique of bridging, McDowell distinguishes between (1) the normal and (2) his own philosophical method. (1) The normal or ordinary method is a kind of "constructive philosophy" that McDowell treats as a deeper dualism; (2) in contrast, his own method is therapeutic ${ }^{14}$ and it refers to the last dualism. In the following, I will first introduce the constructive method of (1) deeper dualism, which is differentiated by the dualisms called "phenomenalism" and "rampant platonism." In the second step, I will present (2) the dualisms of "naturalized platonism" and "bald naturalism," which already point to

12 Cf. J. McDowell, Mind and World: With a New Introduction, 5th ed., Cambridge, MA 2000, p. 93 et seqq. $(\mathrm{V}, \S 3)$.

13 Ibid., p. $93(\mathrm{~V}, \S 3)$.

14 Cf. ibid., p. XI (Intr., $₫ 1$ ), p. XVI et seq. (Intr., $₫ 5$ ), p. XXI et seq. (Intr., $₫ 9$ ), p. XXIII et seq. (Intr., $\$ 10)$, p. 92 et seqq. with Fn. $7(\mathrm{~V}, \S 3)$. 
McDowell's own position of the "naturalism of second nature," which is described in more detail in Section 2.2.

(1) Concerning the deeper dualism, ordinary modern philosophy mediates between both sides of this dualism by favouring one side of the gulf rather than the other. Figuratively speaking, a philosopher stands on one favoured side and uses the existing conceptual material to build up the other one:

Ordinary modern philosophy addresses its derivative dualisms in a characteristic way. It takes its stand on one side of a gulf it aims to bridge, accepting without question the way its target dualism conceives the chosen side. Then it constructs something as close as possible to the conception of the other side that figured in the problems, out of materials that are unproblematically available where it has taken its stand. Of course there no longer seems to be a gulf, but the result is bound to look more or less revisionist. [...] If our construction lacks features that what posed the problem seemed to possess, that is a revisionism that was only to be expected. ${ }^{15}$

For McDowell, phenomenalism ( $\mathrm{Ph}$ ) is an example of deeper dualism and the technique of bridging as described in the quote above: it favours one side of the dualism, i.e. experience $\left(B_{P h}\right)$, and it develops the world out of it $\left(C_{P h}\right)$ as an epiphenomenon; but phenomenalism "aims to overcome anxiety about a gap between experience and the world by constructing the world out of experience, still conceived in just the way that gives rise to the anxiety."16

One can describe this position with Nagel's definition of reductionism, such that phenomenalism is a reductionistic position since it is supposed to be an explanation between two theories, in which one of these theories can be derived from the other by using bridge principles. ${ }^{17}$ In the following, I use a quasi-logical interpretation of bridge principles including conditionals and biconditionals, which are not atypical in the current debate on reductionism. ${ }^{18}$ It should be noted,

15 Ibid., p. 94 et seq. $(\mathrm{V}, \S 3)$.

16 Ibid.

17 Cf. R. van Riel, R. van Gulick, Scientific Reduction, in: The Stanford Encyclopedia of Philosophy (Winter 2019 Edition), ed. E.N. Zalta, URL: https://plato.stanford.edu/archives/spr2019/entries/ scientific-reduction/, sect. 2.2.1.

18 Cf., e.g., M. Esfeld, C. Sachse, P. Soom, Marrying the Merits of Nagelian Reduction and Functional Reduction, "Acta Analytica" 2012, Vol. 27, No. 3, pp. 217-230. Instead of "imply" in bridge principles one can also read "reduced to." 
however, that for much-discussed reasons these syntactical statements cannot be interpreted as fragments of a particular formal system of logic:

$(\mathrm{Ph})$ It is not the case that $B_{P h}$ equals $C_{P h}$. However, $B_{P h}$ may imply $C_{P h}$.

In its most extreme form, the deeper dualism is to be bridged by "rampant platonism" (RP).$^{19}$ This philosophical position represents an extreme because its dualism contains a "spooky" or "supersensible" 20 side on which we can find supernatural and transcendent ideas.

Borrowing an expression from Hegel, we could say that "rampant platonism" contains on the one side an "absolute Beyond," 21 "something that can not be found"; 22 but, on the other side, there is an immanent process - trying to construct the transcendence - which, however, "does not completely attain its goal in the present": 23

Now any platonism has the effect that norms are on the far side of a gulf, and that sets a philosophical task with a familiar shape: to build as close a likeness as possible to what threatened to seem out of reach, using only materials that are reassuringly present on the hither side of the threatening gulf. The aim is that the gulf should disappear. If our construction lacks features that what posed the problem seemed to possess, that is a revisionism that was only to be expected. ${ }^{24}$

For McDowell, we cannot construct the transcendent side $\left(C_{R P}\right)$ out of extensional materials which belong to the other, immanent side $\left(B_{R P}\right)$ of the gulf, and therefore it is not possible for rampant platonism to bridge the gap. In terms of bridge principles, one can sum up:

(RP) It is not the case that $B_{R P}$ equals $C_{R P}$. However, $B_{R P}$ may not imply $C_{R P}$.

(2) However, the situation is different with the positions of the last dualism. McDowell criticizes the fact that ordinary modern philosophy reads a deeper du-

19 Cf. J. McDowell, Mind and World, op. cit., pp. 77-85 (IV, \$\$ 6-9), p. 92 et seq. (V, § 3), p. 110 (VI, \$1), p. 123 (VI, §7).

20 Ibid., p. 82 (IV, \$ 7), pp. 92-95 (V, § 3), p. 176 (III, \$ 1).

21 G.W.F. Hegel, Faith and Knowledge, trans. W. Cerf et al., Albany, NY 1977, p. 147.

22 G.W.F. Hegel, Phenomenology of Spirit, trans. A.V. Miller, Oxford 1977, p. 131 (\$217).

23 Ibid., p. $326(\$ 534)$.

24 J. McDowell, Mind and World, op. cit., p. $94(\mathrm{~V}, \S 3)$. 
alism into Ludwig Wittgenstein's writings, and does not recognize that Wittgenstein transforms the transcendent and "rampant platonism" into a "naturalized" one. ${ }^{25}$ In view of this, both sides come to resemble each other more and more, and for precisely that reason Wittgenstein's "naturalized platonism" illustrates nothing more than the last dualism. Furthermore, McDowell observes this naturalized platonism also in Aristotle's ethics. ${ }^{26} \mathrm{He}$ combines both philosophies with the concepts of Bildung and Erziehung, which at first glance seem to correspond to Richard Rorty's "edification." ${ }^{27}$ But before addressing this similarity in greater detail, it is necessary to gain a better idea of what exactly "naturalized platonism" means.

"Naturalized platonism" (NP) seems to be a special type of platonism that offers an alternative to the one-sided construction of the deeper dualism and the unbridgeable or insurmountable rampant platonism since in neither side seems to be the "absolute Beyond" of its opposite. Thus naturalized platonism ${ }^{28}$ focuses on both sides of the dualism $\left(B_{N P}, C_{N P}\right)$ equally and claims that each side of the gulf is just an expansion of the other. With the help of bridge principles one could, therefore, express this two-sided reductionism by using the following statement:

(NP) It is not the case that $B_{N P}$ is not equal to $C_{N P}$. Therefore, it is the case that $C_{N P}$ is implied from $B_{N P}$ and $B_{N P}$ is implied from $C_{N P}$.

For McDowell, this special kind of platonism has already been mentioned in an aphorism of Wittgenstein's Philosophical Investigations: "Commanding, questioning, recounting, chatting, are as much a part of our natural history as walking, eating, drinking, playing." ${ }^{29}$ By referring to this aphorism, the differences between the two types of platonism can be made clear. Ordinary platonism states

25 Cf. ibid., p. 91 (V, \$ 3), p. 110 (VI, \$1). However, a similar interpretation of Wittgenstein can be found in A.S. Janik, Wie hat Schopenhauer Wittgenstein beeinflußt?, "Schopenhauer-Jahrbuch" 1992, Vol. 73, pp. 69-78.

26 J. McDowell, Mind and World, op. cit., p. 78 et seqq. (IV, $\$ 7$ ).

27 Ibid., p. 87 (IV, \$ 7); R. Rorty, Philosophy and the Mirror of Nature, Princeton, NY 1980, p. 360: "Since 'education' sounds a bit too flat, and Bildung a bit too foreign, I shall use 'edification' to stand for this project of finding new, better, more interesting, more fruitful ways of speaking."

28 The assignment of naturalized platonism to the deeper or last dualism is not fully clear. On the one hand, constructivist traits can be seen here, but, on the other hand, the mediating structure already refers to the position McDowell favours.

29 L. Wittgenstein, Philosophical Investigations: English \& German, 2nd ed., trans. G.E.M. Anscombe, Oxford 1997, p. $12^{\mathrm{e}}(\$ 25)$. 
that ideal or mental entities are outside and beyond the reality and world. But, concerning Wittgenstein and Aristotle, McDowell claims that ideas and mental entities can be interpreted as normal and non-transcendent processes, which are natural to human nature and behaviour: commanding, questioning, recounting, chatting are part of our nature, and this extended concept of nature is called "second nature." ${ }^{30}$

Consequently, the last dualism of this "naturalism of second nature"31 provides an alternative to the deeper and derived dualism because McDowell connects both sides of the dualism "mind and world," "idea and nature" by naturalizing the spooky side and without favouring just one of both sides. But the naturalism of second nature also stopped short of a reductive or "bald naturalism" $(\mathrm{BN})$ in which the formerly transcendent side $\left(C_{B N}\right)$ is totally unenchanted by the naturalized one $\left(B_{B N}\right)$ :

(BN) It is not the case that $B_{B N}$ is not equal to $C_{B N^{*}}$ Therefore, $B_{B N}$ implies $C_{B N}$.

Therefore, the naturalism of second nature upholds that keeping nature "partially enchanted" 32 is necessary - otherwise "we shall certainly need to work at bringing meaning back into the picture when we come to consider human interactions." ${ }^{33}$ Hence, the naturalism of second nature is neither a one-sided construction, like in rampant platonism, nor a one-sided destruction, like in bald naturalism. Rather, it is a therapeutic attempt to partially "exorcize" the spookiness of the more transcendent side, thereby revealing the process of Bildung:

Now it is not even clearly intelligible to suppose a creature might be born at home in the space of reasons. Human beings are not: they are born mere animals, and they are transformed into thinkers and intentional agents in the course of coming to maturity. This transformation risks looking mysterious. But we can take it in our stride if, in our conception of the Bildung that is a central element in the normal maturation of human beings, we give pride of place to the learning of language. ${ }^{34}$

30 Cf. J. McDowell, Mind and World, op. cit., p. XX (Intr., $\$ 8)$, p. 84 et seq. (IV, $\$ 7)$.

$31 \quad$ Cf. ibid., p. 94 et seq., p. $98(\mathrm{~V}, \$ 3)$.

32 Cf. ibid., p. 85 (IV, \$8).

33 Cf. ibid., p. 72 (IV, \$3).

34 Cf. ibid., p. 125 (VI, § 7). 
Unlike Rorty's philosophy of sudden transformation, ${ }^{35}$ McDowell's concepts of Bildung and Erziehung signify constant processes occurring within the side of first nature and the emergence of the side of second nature. Therefore, Bildung becomes the principle of bridging as well as separating both sides of the gulf.

\subsection{Solving the Constructive Dilemma}

The naturalism of second nature is not only an alternative to the deeper dualism; it also provides an answer to the conceptualist question - discussed by Wilfrid Sellars, Gareth Evans and Donald Davidson - of why nature seems to be structured by concepts. Simply said: nature appears to be conceptualized because we are, with our conceptual abilities, a part of nature. ${ }^{36}$ To see the advantage of the naturalism of second nature we have to go back to the beginning of Mind and World. There, McDowell has shown a dualism and a dialectic between the coherence theory of Davidson and Evans's modified myth of the given. Instead of deciding arbitrarily between these two unwanted theories that form a constructive dilemma, ${ }^{37} \mathrm{McD}$ owell offers a third way, which has a therapeutic effect on both theories or positions. The reason why McDowell was unable to make a commitment to Evans or Davidson lies in the fact that the position of the former would necessarily tend towards the non-conceptual, and the latter has to approve a deeper dualism which leads - in the worst case - to rampant platonism:

We are confronted with the dilemma whose horns are embraced by Davidson and Evans, each of them, I claim, deceived in the thought that his position is satisfactory. We can avoid the dilemma. We do not need to say that we have what mere animals have, non-conceptual content, and we have something else as well, since we can conceptualize that content and they cannot. ${ }^{38}$

Both philosophers together form a deeper dualism because each of them takes his stand on one side of the gulf between mind and world. Thus, recent philosophy

35 Cf. R. Rorty, Philosophy and the Mirror of Nature, op. cit., pp. 359, 360.

36 Cf. in detail S. Heßbrüggen-Walter, Spontaneity and Causality: McDowell on the Passivity of Perception, in: John McDowell: Reason and Nature: Lecture and Colloquium in Münster 1999, ed. M. Willaschek, Münster 2000, pp. 21-27.

37 McDowell (Mind and World, op. cit., p. 62 (III, $₫ 6$ ): “[...] Davidson and Evans represent the two horns of a dilemma [...]"; p. 68 (IV, \$ 1): "horn of the dilemma") refers sometimes to the classical concept of "cornutus" (Diog. Laert. II.108f., 135; VI.38; VII.187). 
shows a dialectical movement between each of the two sides, each in turn represented by one of the two philosophers. McDowell refuses to accept a theory of the non-conceptual, like Evans's myth of the given, by having recourse to Kant's slogan "Thoughts without content are empty, intuitions without concepts are blind" and Sellars's kind of inferentialism, ${ }^{39}$ which does not transcend the logical space of reason. ${ }^{40}$ Davidson's coherence theory shows a certain tendency to describe the human mind as an excluded by-product or separate epiphenomenon of nature. Thus, McDowell's refusals result from his "philosophical anxieties" ${ }^{\prime 11}$ that Evans falls back into classical metaphysics and ontology, ${ }^{42}$ while the deeper dualism in Davidson's coherentism runs the risk of becoming a form of supernaturalism. ${ }^{43}$

Because of this, McDowell has - since the first pages of Mind and World committed himself to a third position beyond the one-sided alternatives of Evans and Davidson. This third position attempts to cure the philosophical oscillation and dialectic between the myth of the given and coherentism in order to allow both sides to calm down. ${ }^{44}$ But how can terms, notions, and ideas of the transcendent side relate to our immanent state? McDowell gives a surprising answer to this question:

We should understand what Kant calls "intuition"- experiential intake - not as a bare getting of an extra-conceptual Given, but as a kind of occurrence or state that already has conceptual content. ${ }^{45}$

39 Cf. W. Sellars, Inference and Meaning, "Mind" 1953, Vol. 62, pp. 313-338.

40 Cf. J. McDowell, Mind and World, op. cit., p. XIV (Intr., §4).

${ }^{41}$ Ibid., p. XII (Intr., \$2).

42 This interpretation can be backed by pointing to the historical background. Michael Dummett had proclaimed against Evans in Origins of Analytical Philosophy, Cambridge, MA 1993, p. 4: "A good example of this new trend is Gareth Evans's posthumous book [The Varieties of Reference], which essays an account, independent of language, of what it is to think about an object in each of various ways, and then seeks to explain the different verbal means of effecting reference to an object in terms of these ways of thinking about is. On my characterisation, therefore, Evans was no longer an analytical philosopher." Dummett's criticism of Evans may also be read as or transformed to a criticism addressed to McDowell. Therefore, McDowell immunized his theory in the last chapter of Mind and World (VI, $\$ 8$ ) against this anti-analytical argument of Dummett and also against a fall-back into classical metaphysics and ontology.

43 Cf. J. McDowell, Mind and World, op. cit., p. 78 (IV, $\$ 6$ ), p. 84 (IV, \$ 7), further: p. 88 (V, \$ 1).

44 Cf. ibid., p. 9 (I, $\$ 3$ ), p. 13 (I, \$ 6), p. 76 (IV, \$ 5), p. 86 (IV, \$ 8), p. 95 (V, \$ 3), p. 177 (III, § 2); cf. F. Ellis, On the Dismounting of Seesaws, op. cit.

45 Cf. J. McDowell, Mind and World, op. cit., p. 9 (I, $₫ 4$ ). 
In experience one finds oneself saddled with content. One's conceptual capacities have already been brought into play, in the content's being available to one, before one has any choice in the matter. ${ }^{46}$

Already at the end of his first lecture, McDowell can demonstrate the advantages of his own position. The advantage is especially shown in the fact that there is an alternative to Evans and Davidson:

In this lecture, I have claimed that we are prone to fall into an intolerable oscillation: in one phase we are drawn to a coherentism that cannot make sense of the bearing of thought on objective reality, and in the other phase we recoil into an appeal to the Given, which turns out to be useless. I have urged that in order to escape the oscillation, we need a conception of experiences as states or occurrences that are passive but reflect conceptual capacities, capacities that belong to spontaneity, in operation. ${ }^{47}$

Firstly, it looks like he wishes to avoid the non-conceptual by establishing a mysterious anteriority of the concept (in contrast to nature): ${ }^{48}$ every experience and impression we make already has conceptual content, and therefore they may be "passively received." Unavoidably, we have to ask ourselves: where do the concepts come from which are anterior to the outside world with which they are in contact, and which are anterior to us who have exclusively the ability to produce awareness of concepts? McDowell's reference to Kant's spontaneity (as a solution to this problem) is not satisfactory without a prior explanation of the "naturalism of second nature." Given that McDowell naturalizes conceptual ability or spontaneity in the form of higher oneness by following the "naturalism of second nature" (NN), as we have seen above, his position - which should be an alternative to Evans and Davidson - loses its air of mystery. Simply said, again: nature $\left(B_{N N}\right)$ seems to have conceptual content $\left(C_{N N}\right)$ because we are - as concept users $\left(C_{N N}\right)$ - a part of nature $\left(B_{N N}\right)$. Since both sides of this apparent gulf can now be related to each other, the semantic bridging principle of Bildung or Erziehung can be interpreted in the form of the following biconditional:

$46 \quad$ Ibid., p. $10(\mathrm{I}, \S 5)$.

47 Ibid., p. 23 (I, $\$ 8$ ).

48 This would be a modern version of idealism similar to Fichte's early work in which the "I" posits the "not-I," or to Hegel's late work in which nature is just a repetition of the logos. 
(NN) It is not the case that $B_{N N}$ is not equal to $C_{N N}$. Then and only then $B_{N N}$ implies $C_{N N}$ iff $C_{N N}$ implies $B_{N N}$.

McDowell meets not only the requirement of Kant and Sellars but also makes allowance for Michael Dummett's claim "that the fundamental tenet of analytic philosophy is that philosophical questions about thought are to be approached through language." ${ }^{39}$ By naturalizing the concept or conceptual ability, McDowell offers again a third position as an alternative to Davidson's coherentism and Evans's myth of the given. In this way, the deeper dualism between mind and world, conceptual spontaneity and nature will be transformed in an absolute oneness in which the side of the concept is an expansion of the other side of nature, and both sides shall be combined and separated by the constant process of Bildung, which acts as a principium divisionis as well as a principium identitatis. Through this naturalism of second nature, represented by Bildung that connects both sides of the gulf, the seesaw of recent philosophy should be dismounted and the dialectic should come to an end.

\section{Johann Gottlieb Fichte’s “Absolute Oneness”}

In 1804, Johann Gottlieb Fichte presents the first definitive account of the science of knowing (Wissenschaftslehre). The overall project of the Science of Knowing 1804 is characterized by Fichte as a "complete solution of the riddle of the world and of the consciousness with mathematical evidence" ("vollständige Lösung des Rätsels der Welt mit mathematischer Evidenz"). ${ }^{50}$ His basic thesis is that the solution of that riddle can only be achieved by reciprocally conceiving "multiplicity through oneness and oneness through multiplicity." ${ }^{11}$ If we let $B$ signify "multiplicity" and $C$ "oneness," then we can formulate the hypothesis about the dialecti-

J. McDowell, Mind and World, op. cit., p. 124 (VI, § 8).

50 Cf. J.G. Fichte, Die Wissenschaftslehre: Zweiter Vortrag im Jahre 1804, in: Gesamtausgabe der Bayerischen Akademie der Wissenschaften, Vol. II/8, eds. R. Lauth, H. Gliwitzky, Stuttgart 1985, p. XX, Fn. 13; This translation is my own. The outstanding position of Science of Knowing 1804 in Fichte's late work is made particularly clear by Patrick Tschirner in Totalität und Dialektik. Johann Gottlieb Fichtes späte Wissenschaftslehre oder die lebendige Existenz des Absoluten als sich selbst bildendes Bild, Berlin 2017, esp. $\$ 3$.

51 J.G. Fichte, The Science of Knowing: J.G. Fichte's 1804 Lectures on the Wissenschaftslehre, trans. W.E. Wright, Albany, NY 2005, p. 24 (= J.G. Fichte, Die Wissenschaftslehre, op. cit., pp. 8, 23 et seq.). 
cal structure of the Science of Knowing 1804, which is similar to what McDowell offers in Mind and World.

The Science of Knowing 1804 is thematically and methodically divided into two general parts: the first part refers to logic ("doctrine of truth or reason") 52 and goes bottom-up from multiplicity to oneness by criticizing the established philosophical methods of his time. The details of this part will be discussed in Section 3.1. The second part refers to phenomenology ("doctrine of appearance") and it is a foundation of knowing by leading from oneness top-down to multiplicity. This second primary theme of Fichte's later writing will be discussed in Section 3.2.

\subsection{The Bottom-Up Logic}

In the first part of the Science of Knowing 1804 Fichte begins his search for "absolute oneness" (absoluten Einheit) ${ }^{53}$ which does not turn out to be an "unperceived disjunction" (nicht wahrgenommenen Disjunktion). ${ }^{54}$ But before Fichte gives his insight about this absolute oneness, he shows why all the methods which were already well-established in the history of philosophy have to fail: oneness and multiplicity (Einheit und Mannigfaltigkeit), ${ }^{55}$ thinking and being (Denken und Sein), ${ }^{56}$ or sensibility and supersensibility (Sinnliches und Übersinnliches), ${ }^{57}$ etc., are common disjunctions and familiar dualisms in philosophy for which mediations may be sought; and these mediation attempts are called "connection" $(\text { Band })^{58}$ or "point of oneness" (Einheitspunkt)..$^{59}$ First of all, Fichte holds that semantic connotations are unimportant ${ }^{60}$ in investigating the relationship be-

52 Doctrine of reason (Vernunftlehre) and doctrine of truth (Wahrheitslehre) are typical synonyms for "logic" in the 18th century; cf. W. Risse, Logik I, 6. (art.), in: Historisches Wörterbuch der Philosophie, vol. 5, ed. J. Ritter, Basel 1980, pp. 359-360.

53 J.G. Fichte, The Science of Knowing 1804, p. 23 (= J.G. Fichte, Die Wissenschaftslehre, op. cit., p. 8.4-27).

54 Ibid., p. 25 (= J.G. Fichte, Die Wissenschaftslehre, op. cit., p. 10.22 et seq.).

55 Cf. ibid., p. 23 et seqq. (= J.G. Fichte, Die Wissenschaftslehre, op. cit., p. 8.4 et seqq.).

56 Cf. ibid., p. 25 et seqq. (= J.G. Fichte, Die Wissenschaftslehre, op. cit., p. 12.5 et seqq.).

57 Cf. ibid., p. 31 et seqq. (= J.G. Fichte, Die Wissenschaftslehre, op. cit., p. 26.30 et seqq.).

58 Cf., e.g., ibid., p. 28 (= J.G. Fichte, Die Wissenschaftslehre, op. cit., p. 20.9).

59 Cf., e.g., ibid., p. 41 (= J.G. Fichte, Die Wissenschaftslehre, op. cit., p. 52.27).

60 Cf. ibid., p. 60 (= J.G. Fichte, Die Wissenschaftslehre, op. cit., p. 94.30-33): “Thus away with all words and signs! Nothing remains except our living thinking and insight, which can't be shown on a blackboard nor be represented in any way but can only be surrendered to nature." 
tween concepts in disjunctions. What is more decisive is that all of the concepts mentioned (e.g. thinking and being) are complements or subordinate terms ( $\mathrm{Ne}$ benglieder(Seitenglieder) of disjunctions which could be symbolically represented by $B$ and $C$. In Fichte's opinion, the mediation, the connection, or point of oneness - sometimes represented by him with the letter $\alpha^{61}$ - were not found by his predecessors (such as Spinoza, Jacobi, Kant, Reinhold, or Hegel). Therefore, Fichte tries to prove this hypothesis by using several methods: (1) one method focuses on one side of the disjunction and it is claimed that this side is $\alpha$ (or has the property or value $\alpha$ ); (2) another method does not focus on one side of the disjunction and it is claimed that $\alpha$ is independent of the disjunction.

(1) First, Fichte follows the method of prominent philosophies and focuses on one side of the distinction by identifying this side with the absolute oneness that has been sought. Preferring one side of the distinction will only be possible if the other side is negated. In recognizing that this principle of simultaneous affirmation and negation can be applied to either side of the distinction, Fichte rightly claims that focusing on one side cannot be the method to find the connection $(\alpha)$ or absolute oneness.

An example may be used to illustrate the first problem that Fichte sees in this method: ${ }^{62}$ Let $B$ and $C$ denote two subordinate terms of a distinction. And let $\alpha$ signify the absolute oneness which is either with $B$ or $C$. If a philosopher decides to, e.g., state that $B$ is the absolute $(\alpha)$, this can only be done by negating or subtracting $C$. This equation of $B$ with the property $\alpha$ works if and only if $C$ is negated, abstracted, or subtracted. But based on this premise, $\alpha$ cannot be attributed to $B$ because then the absolute oneness ( $\alpha$ as $B$ ) would be in relation to $C$ and then it would no longer be an absolute oneness. Furthermore, the philosopher can only make the decision to state that $B$ is the absolute on semantic grounds. However, $C$ may also be entitled to be the absolute as $B$, and every problem described above that applies to $B$ also applies to $C$.

The exact logical representation of this problem is tricky due to several reasons. First, the absolute can be understood as a value or property of a variable or term, which itself stands for a judgement about the syntax. ${ }^{63}$ As with many think-

61 Cf., e.g., ibid., p. 24 (= J.G. Fichte, Die Wissenschaftslehre, op. cit., p. 8.22-27).

62 There are more problems which cannot be mentioned here.

63 A similar problem concerning the mixing of syntax and semantics has also been noticed by several authors in Hegel's dialectic (cf. J.E. Maybee, Hegel's Dialectics, op. cit., Sect. 3). The ontological structure, which Fichte analyzes, can be set up as a formal system (cf. J. Lemanski, L. Jansen, 
ers of this epoch, this is the attraction, but also the problem of interpretation. Second, it is not clear which logical rules Fichte accepts and which he does not. ${ }^{64}$ This makes an interpretation with means of current logic problematic.

Fichte also describes this problem as a problem of understanding or defining positions and concepts. Every side of a disjunction or every subordinate term has not only an extension and intension, but rather a complement term - this is the other term within the disjunction - by which it is defined. The importance of the complement term can be seen in the act of understanding or explaining (similar to the definitio genetica sive causalis): we only fully understand or explain concepts or subordinate terms by understanding or explaining what they are not. ${ }^{65}$ To understand a single subordinate term we, therefore, need the complement term, and it seems to be impossible to state that just one subordinate term could be the absolute oneness since this term always depends on the other side of the disjunction. For example, to understand the term "absolute" $(\alpha)$, we have to understand what "relative" means $(\neg \alpha) \cdot{ }^{66}$ Fichte describes this behaviour of concepts or subordinate terms as "reciprocal influence" (gegenseitige Bedingtheit). ${ }^{67}$

(2) This problem also arises if $a$ is not totally identified with $B$ or $C$. In order to clarify the situation, Fichte proposes to examine the disjunction of idealism and realism (Chapters 11-14). In this case, $a$ is neither an idealism $(B)$ nor a realism $(C)$ but rather, e.g., a "higher realism" in which idealism and realism are united. ${ }^{68}$ But this higher realism $\left(C_{1}\right)$ underlies a reciprocal influence of a "higher idealism" $\left(B_{1}\right)$, so that both are subordinate terms of a higher disjunction. ${ }^{69}$ However,

Calculus CL as a Formal System, in: Diagrammatic Representation and Inference: 11th International Conference, Diagrams 2020, Tallinn, Estonia, August 24-28, 2020, Proceedings, eds. A.-V. Pietarinen et al., Cham 2020, pp. 445-460), but then it no longer corresponds to all statements of Fichte.

64 Cf. P. Tschirner, Totalität und Dialektik, op. cit., p. 202 et seqq.

65 Here too, Fichte takes up and modifies classical dialectical principles, such as "determinatio negatio est" or "verum index sui et falsi (et falsum index sui et veri)."

66 Since for Fichte the same applies to the syntax level (see above, prop. 4), from the point of view of modern logic this results in the mixing of syntax and semantics. In particular, I see a mixture of the law of excluded middle and the principle of bivalence in Fichte.

67 J.G. Fichte, The Science of Knowing 1804, p. 64 (= J.G. Fichte, Die Wissenschaftslehre, op. cit., p. 104.22).

68 Such a union succeeds, e.g., through disjunction (cf. J. Lemanski, L. Jansen, Calculus CL as a Formal System, op. cit.). If this semantic assignment is inverted, a union by conjunction is also possible.

69 The indices indicate the hierarchical level: the higher the level, the more subordinated disjunctions are under one term. 
the absolute $(\alpha)$ cannot be found in the disjunction with the index 1, i.e. $B_{1}$ or $C_{1}$, and also not in the even higher disjunction (e.g. $B_{2}$ or $C_{2}$ ). The method in which $\alpha$ is not identified with $B_{i}$ or $C_{i}$ goes bottom-up in infinitum and the absolute is still being sought. In this way, one can find a higher but not an absolute oneness.

Up to now, we have seen that Fichte has examined several methods of finding absolute oneness, but without success. As a result, he has learned that there is an "insurmountable duality" (unüberwindliche Zweiheit) ${ }^{70}$ if he follows the classical methods of philosophy. Consequently, a completely new method has to be used. Fichte, therefore, proposes the following:

The science of knowing does even better than they wish, according to rigorous methods and in the shortest possible way. It does not cut off errors individually, since it is evident that in this work as soon as error is removed on one side it springs up on the other; rather it insists on cutting off the single root for all the various branches. For now, the science of knowing asks for patience and that one not sympathize with the individual appearances of disease, which [our science] has no wish to heal: if only the inner man is first healed, then these individual appearances will take care of themselves. ${ }^{71}$

This is a prime example of Fichte's radical therapeutic technique in his late philosophy: not every singular phenomenon or disjunction has to be bridged. Moreover, the principle of phenomena and disjunctions must be found and examined. Fichte thus reflects on the methods used to overcome the insurmountable duality:

Our procedure is almost always this:

a. we perform something, undoubtedly led in this process by a rule of reason which operates immediately in us. What in this case we really are in our highest peak, and that in which we culminate, is still only facticity.

b. we then search out and reveal the law which guided us mechanically in the initial action. Hence, we see mediately into what we previously had seen into immediately, on the basis of its principle and the ground of its being as it is; and we penetrate it in the origin \{Genesis\} of its determinateness. In this way we will ascend from factical terms to genetic ones. These genetic elements can

70 J.G. Fichte, The Science of Knowing 1804, p. 35 (= J.G. Fichte, Die Wissenschaftslehre, op. cit., p. 40.30f.).

71 Ibid., p. 77 (= J.G. Fichte, Die Wissenschaftslehre, op. cit., p. 136.6-16). 
themselves become factical in another perspective, in which case we would be compelled again in connection with this new facticity to ascend genetically, until we arrive at the absolute source, the source of the science of knowing. ${ }^{72}$

Fichte's own method consists in finding the principle of all disjunctions. Formulated in a more logical way, his question can be articulated this way: how do relations between concepts or subordinate terms work and why are there any? Due to the above-mentioned semantic principle, concepts or subordinate terms such as $B$ or $C$ already behave disjunctively to each other ( $B$ is equivalent to not $C$ ) so that they are structured in such a way that they already imply each other. This is conveyed by the expression "reciprocal influence" of subordinate terms, and as a result Fichte states: "The concept's inward and completely immutable essence has already been acknowledged [...] as a 'through' [Durch]" and this "through" is defined as "the transition that it makes from one to another."73 If the "through"

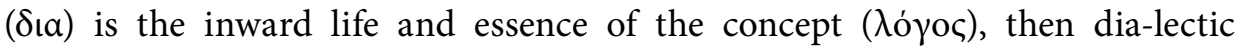

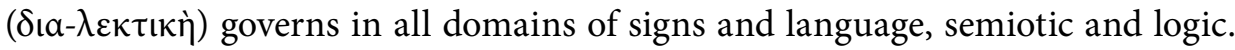
Fichte has thereby found in dialectic "the single root for all the various branches" which can now be "cut off" by a single determinate negation. This negatio simplex of subordinate terms or variables $\left(\left\{\neg B, \neg C, \neg B_{1}, \ldots\right\}\right.$ equals $\left.\neg \alpha\right)$ leads, as an "abstraction from relatedness," to "the very abstraction" $(\neg \neg \alpha)$ which is expressed in the "single insight" that absolute oneness is an "esse in mero actu" 74 which is beyond all subordinate terms because it is itself subordinating every term or concept.

\subsection{The Top-Down Phenomenology}

Lectures 15 and 16 (including the basic proposition ${ }^{75}$ ) mark the transition to the second part of the Science of Knowing 1804, and the "single insight" exhibited there is the terminus a quo of the top-down phenomenology as well as the genesis $^{76}$ by which the construction and formation of the disjunctions can be ex-

72 Ibid., p. 51 (= J.G. Fichte, Die Wissenschaftslehre, op. cit., p. 76.7-19).

73 Ibid., p. 84 (= J.G. Fichte, Die Wissenschaftslehre, op. cit., p. 154.12; p. 154.23 et seq.).

74 Ibid., p. 116 (= J.G. Fichte, Die Wissenschaftslehre, op. cit., p. 228.30).

75 Ibid., p. 121 (= J.G. Fichte, Die Wissenschaftslehre, op. cit., p. 242.1-3): “Being is entirely a selfenclosed singularity \{Singulum\} of immediately living being that can never get outside itself."

76 "Genesis" is the Greek word for "enactment," "Tathandlung"; cf. ibid., p. 106 (= J.G. Fichte, Die Wissenschaftslehre, op. cit., p. 202.18-204.8). 
plained. Whereas previously absolute oneness was sought in the lowly spheres of the disjunctions, Fichte has now the objective of deepening the understanding of the disjunctions by deducing them from absolute oneness. In Lecture 20, the so-called schema of "from" $"$ illustrates the structure of the disjunctions: each subordinate term (e.g. $B_{1}, C_{1}$ ) acts as a higher oneness of two more subordinate terms of a deeper disjunction $\left(B_{0}, C_{0}\right)$. Each of these two subordinate terms acts itself as a higher oneness of two more subordinate terms $\left(B_{-1}, C_{-1}\right)$ and ad infinitum. As before, Fichte has to reflect on the genetic principle of the disjunction, since the structure of subordinate terms $T$ is infinite in both directions, ascending $\left(T_{n+1}\right)$ and descending $\left(T_{n-1}\right)$.

With regard to the upper disjunction, each subordinate term constructs a deeper disjunction (e.g. $C_{1}$ implies $B_{0}$ or $C_{0}$ ); with respect to the lower disjunction, both subordinate terms construct a higher oneness (e.g. $B_{0}$ or $C_{0}$ implies $C_{1}$ ). Therefore, it is not possible to say if a term is primarily part of a "primordial construction" (Urconstruction) or a "re-construction" (Nachconstruction) ${ }^{78}$ and which relation, $\left(C_{1}\right.$ implies $B_{0}$ or $\left.C_{0}\right)$ or $\left(B_{0}\right.$ or $C_{0}$ implies $\left.C_{1}\right)$, is a primordial construction and which is a re-construction. However, the re-construction seems to be a copy of the primordial construction, which is, in contrast to the re-construction, (etiologically) "closer" to the absolute. But every subordinate term or concept behaves as both a primordial construction and a re-construction.

Knowing itself, however, and everything which should arise in it, splits itself absolutely into a duality, whose one term is to be the primordial, and whose other term is to be the reconstruction of the primordial, completely without any diversity of content, and so again absolutely one; differing only in the given form, which obviously indicates a reciprocal relation to one another. (It is really like this in every possible consciousness, if you wish to test the proposition there. Object, representation. $)^{79}$

Due to the fact that the semantic or material content of the term or concept is indifferent ("completely without any diversity of content") and only the form is important ("differing only in the given form"), this implies that it is equal to Fichte whether he signifies a term as primordially constructed or re-constructed.

77 Ibid., p. 151 (= J.G. Fichte, Die Wissenschaftslehre, op. cit., p. 309.12 (Copia!)).

78 Ibid., p. 178 et seq. (= J.G. Fichte, Die Wissenschaftslehre, op. cit., p. 370.20 et seqq.).

79 Ibid., p. 176. (= J.G. Fichte, Die Wissenschaftslehre, op. cit., p. 367.21-27). 
It is only important and decisive that there can be no qualitative change with regard to content, whatever the function of the concept may be. For this reason, there can also be no change in the structure or construction. In other words, this insight is expressed by Fichte as absolute knowing (absolutes Wissen): “This [absolute knowing] is an 'image-making process' \{ein Bilden\} positing itself as an image, and positing a law of the image-making process as an explanation of the image." ${ }^{80}$ Through the genesis - here described as an image-making process - absolute oneness transfers its extensional materiality or content without a qualitative change to every deeper disjunction that is made up of two subordinate terms (e.g. $C_{1}$ implies $B_{0}$ or $C_{0}$ ). And each subordinate term needs the other for it to be understood (e.g. $B_{0}$ implies $C_{0}$ iff $C_{0}$ implies $B_{0}$ ).

Therefore, Fichte's pragmatic turn in the classical German(-speaking) philosophy seems to be fulfilled because the science of knowing has steadily worked towards the goal of a "personal transformation" (Umschaffung unserer selbst): ${ }^{81}$ common or ordinary knowing (gewöhnliches Wissen), which believed that, e.g., either $B$ implies $C$ or $C$ implies $B$, is transformed into absolute knowing, i.e. knowledge of the logical structures of hierarchically organized terms (representing, e.g., philosophical positions, such as idealism or realism). This knowledge includes propositions such as if $B$ is a subordinated term at level 1, i.e. $B_{1}$, then $C_{1}$ is a complementary term to $B_{1}$; or $B$ is $\neg C$ iff $C$ is $\neg B$, then $B$ and $C$ are subordinate terms of the same hierarchical level. But the science of knowing does not end with the pragmatic turn to absolute knowing $(\alpha)$ since absolute knowing is related to the common one $(\neg \alpha)$.

Now, it may happen that ordinary knowing is the primordial condition for the genetic possibility of absolute knowing's existence, or of the science of knowing. Hence, [it may happen] that its determinations can be explained simply from the presupposition that the science of knowing ought to arise $[\ldots] .{ }^{82}$

\footnotetext{
Ibid., p. 180 (= J.G. Fichte, Die Wissenschaftslehre, op. cit., p. 374.28f.).

81 Ibid., p. 28 (= J.G. Fichte, Die Wissenschaftslehre, op. cit., p. 18.34): "What we genuinely comprehend becomes part of ourselves, and if it is a genuinely new insight, it produces a personal transformation. It is impossible that one not be, or that one cease to be, what one has genuinely become $[\ldots]$.."

Ibid., p. 181 (= J.G. Fichte, Die Wissenschaftslehre, op. cit., p. 376.29-32).
} 
Absolute oneness and relative disjunctions (or absolute and ordinary knowing) together form an "organic oneness of both" ${ }^{83}$ because we cannot understand or explain what is absolute if we cannot also understand or explain what is relative (or ordinary). The last standpoint in Fichte's late philosophy concerns the insight that the absolute $(\alpha)$ can only be attained by negating, abstracting, or subtracting all relative disjunctions, and, furthermore, that the absolute has to fall back again in its relationship to the relative $(\neg \alpha)$. From the point of view of the whole science of knowing, the relative and the absolute remain (in themselves) in a state of reciprocal influence ( $\alpha$ implies $\neg \alpha$ iff $\neg \alpha$ implies $\alpha$ ); but from the singular point of view the relative can (for us) be transformed or reduced bottom-up to the absolute ( $\neg \alpha$ implies $\alpha$ ), and the absolute can be transformed top-down to the relative ( $\alpha$ implies $\neg \alpha$ ).

\section{Dialectic in McDowell and Fichte}

In this section, I will discuss two main arguments and topics: in Section 4.1, I will interpret McDowell's approach as an argument that dialectic is a kind of anti-reductionism which is not necessarily identical with holism (or further with individualism). Concerning the reasoning, I am rather of the opinion that dialectic can express a certain positive method that could be superior to other forms of anti-reductionisms. I want to stress with Fichte, in Section 4.2, that dialectic does not cease as an anti-reductionistic position which is opposed to certain reductionisms. Furthermore, dialectic can be interpreted as a method of examining the relationship of reductionism and anti-reductionism itself.

\subsection{Dialectic as a Kind of Anti-Reductionism}

In Section 2, five positions were analyzed: phenomenalism $(\mathrm{Ph})$ and rampant platonism (RP), as two kinds of a deeper dualism, as well as naturalized platonism $(\mathrm{NP})$, bald naturalism $(\mathrm{BN})$ and the naturalism of second nature $(\mathrm{NN})$, as three kinds of a last dualism. I will list the individual bridging principles here, but will omit the index since the assignment of the two variables to the respective dualisms should be clear:

$83 \quad$ Ibid., p. 41 (= J.G. Fichte, Die Wissenschaftslehre, op. cit., p. 54.8f.). 


\section{(1) Kinds of Deeper Dualism}

$(\mathrm{Ph})$ It is not the case that $B$ equals $C$. However, $B$ may imply $C$.

(RP) It is not the case that $B$ equals $C$. However, $B$ may not imply $C$.

\section{(2) Kinds of Last Dualism}

(NP) It is not the case that $B$ is not equal to $C$. Therefore, it is the case that $C$ is implied from $B$ and $B$ is implied from $C$.

(BN) It is not the case that $B$ is not equal to $C$. Therefore, $B$ implies $C$.

(NN) It is not the case that $B$ is not equal to $C$. Then and only then $B$ implies $C$ iff $C$ implies $B$.

Both kinds of deeper dualism differ from the last dualism by their premises and antecedents: whereas $(\mathrm{Ph})$ and $(\mathrm{RP})$ took the premises that it is not the case that $B$ equals $C,(\mathrm{NP}),(\mathrm{BN})$, and $(\mathrm{NN})$ hold that it is the case that $B$ is equal to $C .^{84}$ The fact that (BN) shows similarity to both kinds of the deeper dualism and that McDowell argues for (NN) is based on the consequences: like (Ph) and (RP), $(\mathrm{BN})$ stands on one side of the gulf $(B)$ and construes the other one $(C)$ out of it. This methodological strategy of constructing or bridging, which I have described in quasi-logical terms, e.g. $B$ implies $C$, can be characterized as an argumentative attribute of reductionism: $(\mathrm{Ph})$ takes its stand $(B)$ on experience, $(\mathrm{RP})$ on immanence, and (BN) on the natural world, and all three together try to involve opposite positions $(C)$, such as world, transcendence, or mind.

Following McDowell, all three reductionisms are mainly differentiated from one another in that they use semantically different concepts for their reductionistic starting point $(B)$ and their targeted objective $(C)$, on the one hand, and that they fail because of different results, on the other. Whereas the former differentiation can be regarded as unimportant since it just relates to the extensional force of the respective concept, the latter differentiation concerning the fallibility of each reductionism is more interesting. It is not impossible to interpret McDowell's

84 As was hopefully evident from Section 2, McDowell sees equality between $B$ and $C$ under different aspects, sometimes as a semantic equality, sometimes as an extensional equality, equality at the level of phenomena, etc. Here, however, an attempt has been made to present this always by using the expression of implication. 
discussion of the three reductionisms as having anti-reductionistic arguments (e.g. the anti-reductionistic argument of inexplicable phenomena which corresponds to the spooky side of platonism), but I think that they fail for another reason. Each of the three positions of reductionism can be associated with one of the three forms of the Agrippa trilemma: $(\mathrm{Ph})$ fails because its result is identical to the premise (circularity); (RP) fails because its premise requires that $B$ can never reach $C$ so that no result can be found (progressus ad infinitum); and (BN) claims dogmatically that $C$ has always been part of $B$ (assumption).

As a consequence of the fallibility of each reductionism, it is expected that McDowell opts for an anti-reductionistic position, and anti-reductionistic positions are often equated with holism (or sometimes with individualism). ${ }^{85}$ But to claim holism (or individualism) instead of reductionism would be nothing else than another kind of dogmatic assumption and, therefore, argumentatively similar to bald naturalism. This problem has previously been highlighted by Duncan Pritchard, as I have mentioned in Section 1: anti-reductionism, as the word indicates, would only be a negation or denial of reductionism, without offering a positive argumentative method. Furthermore, if one identifies anti-reductionism with holism (or individualism), it is to be assumed that normally reasoning for anti-reductionism is just a reversal of reductive argumentation: since it is accepted that one side of the gulf is constructed by the other one, both sides apply equally.

I believe that McDowell's (NN) is a kind of anti-reductionism that neither inverts the reductive argumentation nor simply negates reductionism. ${ }^{86}$ Like (RP) and dissimilar to $(\mathrm{Ph})$ and $(\mathrm{BN}),(\mathrm{NN})$ does neither claim that $B$ does not equal $C(\mathrm{Ph})$ nor $B$ equals $C(\mathrm{BN})$. Of course, one can expect now that $(\mathrm{NN})$ is liable to the same problem as (RP), i.e. that there is "something that can not be found" (Hegel), so that the argumentation goes ad infinitum. But McDowell exemplifies with the binary opposite concepts of mind (Davidson) and world (Evans) that the result is given in the process itself. I repeat the consequence of Section 2 in similar words: the world $(B)$ is a part of the mind $(C)$ since the mind $(C)$ is a part of the world (B): $B$ implies $C$ iff $C$ implies $B$. In contrast to (RP), (NN) demonstrates with the concepts of "mind" and "world" that $C$ is something that can be found

85 Cf., e.g., J. Mittelstraß, Theoria: Chapters in the Philosophy of Science, Berlin 2018, Chap. 1.

86 As in many theoretical debates in analytical philosophy, the binary positions can easily be exchanged, e.g. in the following, reductionism and non-reductionism can be substituted for conceptualism and non-conceptualism. 
by $B$, though only if $B$ can be found by $C$. Therefore, (NN) avoids the questionbegging problems of $(\mathrm{Ph})$ and $(\mathrm{BN})$, and escapes also the problem of fruitlessness, which is represented by (RP).

Moreover, if one is willing to interpret the concepts of "mind" and "world" rhetorically as a merism, then she is able to interpret the argumentative structure " $B$ implies $C$ iff $C$ implies $B$ " as a form of holism - but this holism is the result of a two-sided process and not only simple assertion. In any case, McDowell's argumentative structure shows that anti-reductionism is not just a negative reaction to reductionism, but can also offer a positive method and a process which goes dialectically from $B$ to $C$ and vice versa.

\subsection{Dialectic as a Debate on Reductionism and Anti-Reductionism}

In Section 4.1, we have seen that reductionism can be interpreted as a philosophical position that stands on one side of the gulf $(B)$ and construes the other one $(C)$ out of it, in short: $B$ implies $C$. We have also seen that the anti-reductionistic dialectic is neither only a negative answer to reductionism nor an approach necessarily identical to holism (or individualism). Instead, with McDowell anti-reductionism can be interpreted in a positive way as a dialectical method or figure ( $B$ implies $C$ iff $C$ implies $B$ ). I believe that what we have said with McDowell in Section 4.1 could have also been exemplified by Fichte. For example, Valentin Pluder has done something similar with Fichte's debate on Kant and on idealism and realism in the Science of Knowing $1804{ }^{87}$ For instance, Fichte demonstrates that each idealism as well as realism maintains to take the right side of the gulf and to construe the opposite out of it, i.e. $B$ implies $C$ or $C$ implies $B$. Like McDowell's (Ph), (RP), etc., neither of those positions is convincing and both argumentation strategies just lead to higher idealisms and higher realisms that argue reductively in the same manner as their predecessors (normal idealism and realism and so on).

Similar to McDowell, Fichte offers a third way between idealism and realism, which has a therapeutic effect on both sides. In the implementation of the therapy, Fichte and McDowell differ considerably from one another: while for McDowell the anti-reductionistic dialectic is the solution of the problem of reductionism (as we have seen in Section 4.1), for Fichte dialectic itself seems to be

${ }_{87}$ V. Pluder, Die Vermittlung von Idealismus und Realismus, op. cit. 
the problem. For Fichte, the debate on idealism and realism, which form both sides of the gulf, is dialectical itself since, first of all, "dialectic" is the word that indicates that each of the two reductionisms in the one debate claim to be right. For instance, idealism argues that $B$ implies $C$ iff realism asserts that $C$ implies $B$ and vice versa. While for McDowell the dialectical method or figure ( $B$ implies $C$ iff $C$ implies $B$ ) is the solution to the problem of mutually incompatible reductionisms, Fichte argues at first that a therapy can only work on reductionism, if one is able to act on both sides of the gulf at the same time, e.g. by negation. The result that both sides calm down simultaneously will only be possible if one is willing to avoid the dialectical debate itself ( $B$ implies $C$ iff $C$ implies $B$ ). So far it looks as if for McDowell dialectic is the anti-reductionistic solution of the problem of reductionism, and as if for Fichte dialectic is the problem of reductionism that can bring us to anti-reductionism, on the condition of avoiding dialectic itself. In simple words, McDowell's therapy seems to be a harmonization by dialectic, while Fichte's therapy seems to be an amputation of dialectic. But this is just one insight into the science of knowing, which may later turn out to be incorrect or incomplete.

Fichte goes on and argues that reductionism can be identified with ordinary knowing. In contrast, anti-reductionism is equal to absolute knowing. Like Rorty and McDowell, Fichte assures us that there is a process of edification and transformation that leads from ordinary knowing to the absolute one. What makes Fichte interesting for us today, is the insight that ordinary knowing (reductionism $=\neg \alpha$ ) and absolute knowing (anti-reductionism $=\alpha$ ) are themselves in a dialectical relationship to one another ${ }^{88}$ Here again (as explained in Section 2.1), the fundamental principle is that we can only fully understand or explain absolute knowing by understanding or explaining the ordinary one and vice versa. In other words, anti-reductionism behaves analogously to reductionism, just as idealism and realism do.

From this insight, two hypotheses can be derived. (1) First of all, if anti-reductionism is just one side of the gulf in opposition to reductionism, then anti-reductionism cannot argue in another way than reductionism can, i.e. $B$ implies C. (2) Second, if anti-reductionism is just one side of the gulf in opposition to reductionism, then there can be no one-side technique of bridging the gulf

88 However, as I pointed out above, this fertility is caused by the problem that one must either say that Fichte violates the rules of modern logic (which of course he does not know) or that Fichte cannot be interpreted meaningfully with the rules of modern logic. 
that is satisfactory or convincing, but merely a double-sided technique which is called "dialectic," i.e. $B$ implies $C$ iff $C$ implies $B$. I think that it is not necessary to argue in detail that both hypotheses are derived from the principles which were detailed before. But I will give a short comment on both hypotheses. (1) It might seem odd, given that anti-reductionism seems to be another form of reductionism itself. But this is not, however, meant in a semantic way, but rather in a methodological way: anti-reductionism is the opposite of reductionism, but both argue against one another in the same way which originates in debates in which two purely reductionistic sides are involved, e.g. idealism and realism. (2) What initially appeared to be the problem of reductionism developed within Fichte's argumentation as the endpoint of every debate with two inherently contradictory positions in which each side tries to reduce the other one to itself. If it cannot be convincing that one position is right, Fichte tries to develop a point of view in which each position applies with equal accuracy and validity at the same time. At this point, Fichte finds out that the amputation of dialectic cannot be a therapy that leads from reductionism (ordinary knowing) to anti-reductionism (absolute knowing) since both positions form two sides of the gulf which behave like normal reductionism itself. Therefore, dialectic cannot be treated, but rather is the treatment of his therapy.

I think that, on this issue, Fichte is close to McDowell, as we have seen at the end of Section 4.1. In my view, the advantage of Fichte's doctrine is not that he represents an anti-reductionistic position, ${ }^{89}$ but rather that he reflects on the debate of reductionism and anti-reductionism itself.

\section{Conclusion}

I will conclude by enumerating three systematic results from both approaches given in the previous sections that may be interesting to current debates on reductionism, anti-reductionism, and dialectic:

(1) Anti-reductionism is not necessarily identical to holism or individualism, but it can also be equal to dialectic. Therefore, dialectic is an alternative to reductionism and normal anti-reductionism.

89 In this paper I have refrained from accusing McDowell of a reductionistic standpoint of conceptualism. 
(2) However, anti-reductionism stands in opposition to reductionism and cannot argue in another way than reductionism can; even the double-sided method of dialectic is just a one-sided attempt to bridge the gulf to non-dialectical positions.

(3) The debate on reductionism and anti-reductionism can at least be interpreted as a form of dialectic itself in which both sides claim to be the right one simultaneously, which can involve the other one in or construe the other one out of it.

If one is looking for an answer on the question of whether McDowell or Fichte succeeds in showing that dialectic bridges the gulf, then I would tend to reject the question itself. Since dialectic is for both the method that shows how far it is possible to go within a debate of two incompatible positions and without arguing dogmatically for just one of two positions. But the only reason why I would plead for studying Fichte today and not only McDowell concerns the point that Fichte reflects on the gulf between reductionism and anti-reductionism itself, whereas McDowell is satisfied with having bridged the gulf between the two main reductionisms (mind and word).

Concerning our three results, the question remains if Steve Gerrard and Fiona Ellis could be right in criticizing the dialectician as someone who is clothed in "metaphysical mystery" by "building more epicycles in the metaphysical castle." 90 I think the criticism does not appear unjustified, but what we can learn from Fichte and McDowell could be that there is just one alternative to dialectic: to build more and more arguments in our reductionistic castles. Being a non-dialectician or a dialectician depends on the question of what philosophy should actually achieve: do we want to stand on one side and build a one-way bridge or do we want to visit both sides by using a two-way bridge. However, we can conclusively state with Rorty that "whichever happens, however, there is no danger of philosophy's 'coming to an end."'91

90 Cf. S. Gerrard, A Philosophy of Mathematics between Two Camps, in: The Cambridge Companion to Wittgenstein, ed. Hans Sluga et al., Cambridge 1996, p. 171; F. Ellis, On the Dismounting of Seesaws, op. cit.

91 Cf. R. Rorty, Philosophy and the Mirror of Nature, op. cit., p. 394. 


\section{Acknowledgement}

The present paper is the result of a series of attempts to bring the dialectical method into a more or less logical form. My special thanks go to Benjamin Daise (Hobart and William Smith Colleges), who has motivated me again and again to make this attempt, and who has helped me with numerous comments. I would also like to thank the two anonymous reviewers of Edukacja Filozoficzna.

\section{Bibliography}

Brandom R., Tales of the Mighty Dead: Historical Essays in the Metaphysics of Intentionality, Cambridge, MA 2002.

Browning J., McDowell and the Contents of Intuition, "Dialectica" 2019, Vol. 73, No. 1-2, pp. 83-104.

Dews P., Nature and Subjectivity: Fichte's Role in the Pippin/McDowell Debate in the Light of His Neo-Kantian Reception, "Fichte-Studien" 2010, Vol. 35, pp. 227-243.

Dummett M., Origins of Analytical Philosophy, Cambridge, MA 1993.

Esfeld M., Sachse C., Soom P., Marrying the Merits of Nagelian Reduction and Functional Reduction, "Acta Analytica" 2012, Vol. 27, No. 3, pp. 217-230.

Ellis F., On the Dismounting ofSeesaws, "Philosophy" 2001, Vol. 76, No. 1, pp. 31-54. Fichte J.G., Die Wissenschaftslehre: Zweiter Vortrag im Jahre 1804, in: Gesamtausgabe der Bayerischen Akademie der Wissenschaften, Vol. II/8, eds. R. Lauth, H. Gliwitzky, Stuttgart 1985.

Fichte J.G., Concerning the Concept of the Wissenschaftslehre, in: J.G. Fichte, Early Philosophical Writings, trans. and ed. D. Breazeale, Ithaca, NY 1993, pp. 87-137. Fichte J.G., The Science of Knowing: J.G. Fichte's 1804 Lectures on the Wissenschaftslehre, trans. W.E. Wright, Albany, NY 2005.

Gerrard S., A Philosophy of Mathematics between Two Camps, in: The Cambridge Companion to Wittgenstein, ed. Hans Sluga et al., Cambridge 1996, pp. 171-198. di Giovanni G., The Jacobi-Fichte-Reinhold Dialogue and Analytical Philosophy, "Fichte-Studien" 1998, Vol. 14, pp. 63-87.

Gulli M., Inferenzialismo e dialettica speculativa: Robert Brandom e la lettura critica di Hegel, "Giornale di metafisica" 2007, Vol. 3, No. 2, pp. 731-756.

Hegel G.W.F., Faith and Knowledge, trans. W. Cerf et al., Albany, NY 1977. 
Hegel G.W.F., Phenomenology of Spirit, trans. A.V. Miller, Oxford 1977.

Heßbrüggen-Walter S., Spontaneity and Causality: McDowell on the Passivity of Perception, in: John McDowell: Reason and Nature: Lecture and Colloquium in Münster 1999, ed. M. Willaschek, Münster 2000, pp. 21-27.

Houlgate S., McDowell, Hegel, and the "Phenomenology of Spirit", "Owl of Minerva" 2009/10, Vol. 41, pp. 13-26.

Janik A.S., Wie hat Schopenhauer Wittgenstein beeinflußt?, "Schopenhauer-Jahrbuch" 1992, Vol. 73, pp. 69-78.

Jones R.H., Reductionism: Analysis and the Fullness of Reality, Lewisburg 2000.

Lemanski J., An Analogy between Hegel's Theory of Recognition and Ficino's Theory of Love, "British Journal for the History of Philosophy" 2019, Vol. 27, No. 1, pp. 95-113.

Lemanski J., Jansen L., Calculus CL as a Formal System, in: Diagrammatic Representation and Inference: 11th International Conference, Diagrams 2020, Tallinn, Estonia, August 24-28, 2020, Proceedings, eds. A.-V. Pietarinen et al., Cham 2020, pp. 445-460.

Limnatis N., The Dimensions of Hegel's Dialectic, London 2010.

Maybee J.E., Hegel's Dialectics, in: The Stanford Encyclopedia of Philosophy (Winter 2019 Edition), ed. E.N. Zalta, URL: https://plato.stanford.edu/archives/ win2019/entries/hegel-dialectics/.

McDowell J., Mind and World: With a New Introduction, 5th ed., Cambridge, MA 2000.

McDowell J., Having the World in View: Essays on Kant, Hegel, and Sellars, Cambridge, MA 2009.

Mittelstraß J., Theoria: Chapters in the Philosophy of Science, Berlin 2018.

Morrison B., Mind, World and Language: McDowell and Kovesi, "Ratio: An International Journal of Analytic Philosophy" 2002, Vol. 15, No. 3, pp. 293-308.

Pluder V., Die Vermittlung von Idealismus und Realismus in der Klassischen Deutschen Philosophie, Stuttgart-Bad Cannstatt 2013.

Pritchard D., A Defence of Quasi-Reductionism in the Epistemology of Testimony, "Philosophica" 2006, Vol. 78, pp. 13-28.

Rockmore T., Analytic Philosophy and the Hegelian Turn, "The Review of Metaphysics” 2001, Vol. 55, No. 2, pp. 339-370.

Rorty R., Philosophy and the Mirror of Nature, Princeton, NY 1980. 
Risse W., Logik I, 6. (art.), in: Historisches Wörterbuch der Philosophie, Vol. 5, ed. J. Ritter, Basel 1980, pp. 359-360.

Sellars W., Inference and Meaning, "Mind" 1953, Vol. 62, pp. 313-338.

Sellars W., Empricism and the Philosophy of Mind, Cambridge, MA 1997.

Testa I., Criticism from Within Nature: The Dialectic Between First and Second Nature from McDowell to Adorno, "Philosophy \& Social Criticism" 2007, Vol. 33, pp. 473-498.

Tschirner P., Totalität und Dialektik. Johann Gottlieb Fichtes späte Wissenschaftslehre oder die lebendige Existenz des Absoluten als sich selbst bildendes Bild, Berlin 2017.

van Riel R., Nagelian Reduction beyond the Nagel Model, "Philosophy of Science" 2011, Vol. 78, No. 3, pp. 353-375.

van Riel R., Van Gulick R., Scientific Reduction, in: The Stanford Encyclopedia of Philosophy (Winter 2019 Edition), ed. E.N. Zalta, URL: https://plato.stanford. edu/archives/spr2019/entries/scientific-reduction/.

Whyman T., The Irrational in the Rational, or: John McDowell's Dialectic of Enlightenment, "Inquiry: An Interdisciplinary Journal of Philosophy" 2018, pp. 1-23.

Wittgenstein L., Philosophical Investigations: English \& German, 2nd ed., trans. G.E.M. Anscombe, Oxford 1997.

\section{Summary}

"Dialectic" has been a matter of growing interest in contemporary philosophy. The present article analyzes dialectical methods and positions them by reference to two paradigmatic texts of German idealism and analytic philosophy, i.e. J.G. Fichte's Science of Knowing (1804) and J. McDowell's Mind and World. Both dialectical approaches will be interpreted with regard to their contribution in the debate on reductionism and anti-reductionism: both Fichte and McDowell claim that philosophical positions and logical terms stand in a dualistic relationship to one another, on the one hand, but are separated by a gulf, on the other. I will argue that for McDowell dialectic seems to be an alternative to one-sided reductionisms as well as to normal anti-reductionistic holism. Furthermore, for 
Fichte dialectic is an adequate method for describing the relationship of reductionism and anti-reductionism itself. Both see in dialectic a technique for bridging the gulf between binary opposite terms of logic as well as mutually exclusive positions, such as mind and world, subject and object, or idealism and realism.

Key words: dialectic, reductionism, anti-reductionism, conceptualism, bridge principles

\section{Streszczenie}

\section{Techniki budowania mostu nad przepaścią: dialektyka i redukcjonizm u McDowella i Fichtego}

We współczesnej filozofii „dialektyka” cieszy się rosnącym zainteresowaniem. Artykuł ten analizuje metody dialektyczne i rozważa je w odniesieniu do dwóch paradygmatycznych tekstów z obszarów idealizmu niemieckiego i filozofii analitycznej, tj. Teorii wiedzy J.G. Fichtego (1804) oraz Umysłu i świata J. McDowella. Przedstawione w nich ujęcia dialektyczne zostaną zinterpretowane w kontekście ich wkładu do debaty na temat redukcjonizmu i antyredukcjonizmu. Zarówno Fichte, jak i McDowell uważają, że stanowiska filozoficzne oraz terminy logiczne: $\mathrm{z}$ jednej strony są ze sobą powiązane, $\mathrm{z}$ drugiej zaś - oddzielone są od siebie przepaścią. Pokażę, że dla McDowella dialektyka wydaje się alternatywą zarówno dla jednostronnego redukcjonizmu, jak i dla normalnego antyredukcjonistycznego holizmu. Ponadto zaś - że dla Fichtego dialektyka jest adekwatną metodą opisywania relacji między redukcjonizmem i antyredukcjonizmem. Obaj myśliciele widzą w dialektyce technikę budowania mostu nad przepaścią rozciągającą się pomiędzy binarnie przeciwnymi terminami logicznymi, a także pomiędzy tym, co zdaje się wzajemnie wykluczać, jak umysł i świat, podmiot i przedmiot czy idealizm i realizm.

Słowa kluczowe: dialektyka, redukcjonizm, antyredukcjonizm, konceptualizm, zasady pomostowe 